\title{
Stimulus Iklan, Positive Electronic Word of Mouth (eWOM) dan Belanja Impulsif: Dampak Mediasi Motif Hedonis Pembelanja Online
}

\author{
Nani Ernawati \\ Universitas Islam Nusantara Bandung, Indonesia \\ *naniernawati@uninus.ac.id
}

\begin{abstract}
Abstrak
Penelitian ini ditujukan untuk menguji kerangka teoritis yang menjelaskan bagaimana peran mediasi motivasi belanja hedonis dalam hubungannya dengan stimulus iklan, cerita dari mulut ke mulut (electronics word of mouth-eWOM), dan belanja impulsif pembelanja secara daring (online). Survey dilakukan terhadap 384 warga Kota Bandung yang dipilih dengan metode systematic random sampling. Data dihimpun dengan menggunakan instrumen kuesioner tertutup yang telah diuji aspek validitas dan reliabilitasnya. Data dianalisis dengan menggunakan analisis jalur, yaitu salah satu varian analisis regresi. Penelitian dilakukan pada bulan Maret s.d April 2021 dan hasilnya menunjukan menunjukkan bahwa stimulus iklan berpengaruh positif langsung terhadap motivasi belanja hedonis dan belanja impulsif pembelanja online. Sementara, eWOM tidak berpengaruh terhadap motivasi belanja hedonis tetapi berpengaruh langsung terhadap belanja impulsif. Selain itu, terbukti motif belanja hedonis memediasi pengaruh stimulus iklan terhadap belanja impulsif. Pengiklanan yang masif dan persuasif tampaknya harus dijadikan strategi andalan bagi setiap lokapasar untuk membangkitkan motif belanja hedonis dan perilaku belanja impulsif pembelanja toko online. Hasil penelitian diharapkan dapat menjadi rujukan alternatif bagi peneliti dan praktisi dalam memahami peran motif belanja hedonis dan perilaku belanja impulsif.
\end{abstract}

Kata kunci: motivasi belanja hedonis, stimulus iklan, cerita dari mulut ke mulut secara elektronik, eWOM, belanja impulsif.

\section{Pendahuluan}

\section{Latar Belakang}

Pada zaman yang semakin moderen sekarang ini banyak sekali penemuan teknologi yang dapat membantu aktivitas manusia, salah satunya adalah teknologi di bidang informasi yaitu internet. Pengguna internet di Indonesia terus mengalami pertumbuhan setiap tahunnya, dan pada tahun 2018 mencapai 171,2 juta jiwa, atau meningkat 10,12\% dibandingkan tahun sebelumnya (APJII, 2019). Dengan tingginya pertumbuhan penggunaan internet serta bertambahnya kemudahan dalam pemakaiannya telah mengakibatkan banyak perubahan di segala aspek kehidupan. Satu diantaranya adalah hadirnya lokapasar (marketplace) yang memiliki konsep bisnis consumer to consumer yaitu jenis bisnis lokapasar yang hanya menyediakan sarana (platform) untuk memfasilitasi bertemunya pembeli dan penjual, namun tidak bertanggung jawab atas barang-barang yang dijual. Kemunculan kegiatan komersial dan bisnis melalui internet (e-commerce dan e-business) menandakan adanya penggunaan teknologi informasi dan pola komunikasi yang baru pula. Kemajuan teknologi dalam transportasi, pengiriman barang, dan komunikasi telah mempermudah kegiatan pemasaran dan 
telah mentransformasi pasar menjadi pasar digital. Pembelian online merupakan sebuah terobosan dalam era digitalisasi dunia pemasaran, dan belanja melalui internet kini merupakan cara baru untuk berbelanja.

Perkembangan E-commerce telah berkembang hampir di seluruh negara, termasuk di Indonesia. Sejak tahun 2014 Euromonitor mencatat bahwa penjualan secara daring di Indonesia mencapai US\$1,1 miliar. Saat ini setidaknya tercatat 44 situs lokapasar yang beroperasi di Indonesia dengan pemimpin pasarnya yaitu Shopee, Tokopedia, Bukalapak, Lazada, dan Blibli. Banyaknya perusahaan E-commerce serta beragamnya jenis layanan yang ditawarkan membuat konsumen lebih leluasa dalam memilih toko online. Tetapi di lain pihak banyaknya perusahaan E-commerce yang beroperasi juga menyebabkan persaingan yang ketat untuk menarik minat seseorang berkunjung dan melakukan pembelian melalui situs miliknya makin tidak terhindarkan. Oleh karenanya setiap pelaku lokapasar diantaranya harus makin memahami perilaku dan kebutuhan konsumennya secara tepat.

Salah satu strategi yang dilakukan pelaku lokapasar untuk menarik konsumen yaitu melalui pengiklanan yang masif dan terus menerus. Iklan dapat membangkitkan emosi positif konsumen (Verhagen \& Dolen, 2011), yaitu salah satu komponen motif belanja hedonis. Pada gilirannya motif hedonis inilah yang akan mendorong konsumen untuk berbelanja secara impulsif (impulsive buying). Belanja impulsif secara sederhana dipahami sebagai perilaku pembelian yang tidak didasarkan atas rencana pembelian sebelumnya, dan umumnya terjadi karena dorongan seketika atau stimulus untuk memiliki sesuatu barang yang dilihatnya saat itu (Solomon et al., 2006). Hedonic shopping value memainkan peran penting dalam belanja impulsif karena sering didorong oleh keinginan hedonis atau sebab lain di luar alasan ekonomi (Park et al., 2006).

Oleh karena itu toko online merancang tampilan iklannya agar menarik, mendorong dan menggoda konsumen untuk berbelanja tanpa rencana dan merangsang motif hedonisnya. Hasil penelitian Ozen and Engizek (2014) menunjukkan bahwa pembeli online lebih cenderung impulsif dibandingkan pembeli tradisional. Pengiklanan yang disertai dengan program promosi juga diperkirakan lebih mendorong konsumen untuk berperilaku hedonis, yaitu melalui komponen nilai belanja (value shopping). Jadi iklan yang terus menerus disampaikan oleh situs lokapasar dapat mempengaruhi konsumen untuk berbelanja secara impulsif melalui pembangkitan motif hedonisnya

Faktor lain yang dapat mendorong belanja impulsif adalah cerita dari mulut ke mulut baik secara tradional maupun melalui pemanfaatan media elektronik (Electronic Word of Mouth-eWOM) secara berantai. Jika seorang konsumen merasa puas pada suatu produk yang dibelinya maka ada kecenderungan untuk mengkomunikasikan produk tersebut kepada orang lain. Tindakan ini secara tidak langsung membuat produk tersebut terlihat baik oleh orang lain yang mungkin saja belum mencoba menggunakan produk tersebut.

\section{Masalah, tujuan dan manfaat penelitian}

Penelitian ini dimaksudkan untuk mengungkapkan dan memahami perilaku belanja impulsif konsumen toko online. Hubungan antara posisi motif hedonis dengan perilaku belanja impulsif yang hingga kini masih menjadi materi diskusi yang menarik di kalangan para peneliti. Oleh karenanya rumusan masalah penelitian ini adalah apakah:

1) Stimulus iklan berpengaruh positif dan langsung terhadap motif hedonis pembelanja online?

2) eWOM yang positif berpengaruh positif dan langsung terhadap motif hedonis pada pembelanja online? 
3) Stimulus iklan berpengaruh positif dan langsung terhadap perilaku belanja impulsif pembelanja online?

4) eWOM yang positif berpengaruh positif dan langsung terhadap perilaku belanja impulsif pembelanja online?

5) Motif hedonis berpengaruh positif dan langsung terhadap perilaku belanja impulsif pembelanja online?

6) Stimulus iklan berpengaruh positif dan tidak langsung terhadap perilaku belanja impulsif melalui variabel mediasi motif hedonis?

7) eWOM yang positif berpengaruh positif dan tidak langsung terhadap perilaku belanja impulsif melalui variabel mediasi motif hedonis?

Penelitian ini bertujuan untuk menganalisis dan memetakan pengaruh langsung dan pengaruh tidak langsung stimulus iklan dan $e W O M$ yang positif terhadap perilaku belanja impusif konsumen toko online melalui variabel mediasi motif hedonis. Hasil penelitian ini diharapkan dapat melengkapi dan dijadikan rujukan alternatif bagi penelitian-penelitian berikutnya terutama yang berkaitan dengan topik perilaku konsumen.

\section{Landasan Teori \& Pengembangan Hipotesis}

\section{Belanja Impulsif (Impulsive Buying)}

Baik belanja hedonis ataupun utilitirian, keduanya adalah sebuah keputusan pembelian yang ditetapkan oleh konsumen, yaitu merupakan tahap evaluasi konsumen dari preferensi diantara merek dan sekian pilihan dan mungkin juga dari niat untuk membeli merek yang paling disukai. Beberapa tahapan yang dilakukan konsumen pada saat melakukan proses keputusan pembelian, biasanya meliputi: problem and needs recognition, information search, evaluation of alternative, purchase decision, dan post purchase behavior (Armstrong \& Kotler, 2015). Tahap-tahap inilah yang akan menghasilkan keputusan untuk membeli atau tidak.

Namun kenyataannya tidak setiap pembelian didasari oleh proses tersebut, karena adakalanya individu membeli sesuatu secara spontan dan tidak terencana. Pada kondisi tersebut, fase yang seharusnya digunakan untuk membuat berbagai pertimbangan yang bersifat kognitif, kini digantikan dan didominasi oleh faktor emosi seperti rasa senang dan kepuasaan sesaat sewaktu membeli. Perilaku ini sering disebut sebagai perilaku belanja impulsif (impulse buying behavior).

Boleh jadi sebagian besar konsumen pernah merasakan atau melakukan pembelian secara impulsif (J.Kacen \& Lee, 2002), dan umumnya terjadi karena dorongan seketika atau stimulus untuk memiliki sesuatu barang yang dilihatnya saat itu (Solomon et al., 2002). Konsumen yang tergolong pembeli impulsif termasuk pada segmen yang selalu mencari halhal baru (experiencer) yang biasanya merupakan kelompok usia remaja, menyukai variasi, menyukai hal-hal yang tidak biasa/baru (Hawkins \& Mothersbaugh, 2010). Berikutnya Verhagen \& Dolen (2011) menyatakan pembelian impulsif terjadi ketika seseorang mengalami dorongan yang tidak tertahankan untuk mendapatkan suatu produk tanpa pertimbangan yang matang. Sementara Silvera et al., (2008) mengemukakan bahwa pembeli impulsif lebih memperhatikan pertimbangan hedonis dibandingkan pertimbangan pada saat belanja pada umumnya (utilitarian). Ozen \& Engizek, (2013) menegaskan pembelian secara daring lebih cenderung impulsif dibandingkan pembeli tradisional.

Beberapa faktor diperhitungkan sebagai stimulus terjadinya belanja impulsif, baik yang muncul konsumennya (Youn \& Faber, 2000) atau karena faktor lingkungan (Chang et al., 2014). Stimulus internal diantaranya yaitu kondisi hati dan emosi konsumen (Bell, 2011) dan 
faktor demografik (Tice et al., 2001). Emosi dapat disetarakan dengan suasana hati yang dapat mendorong pengambilan keputusan oleh konsumen. Beberapa penelitian menunjukkan kecenderungan ini, diantaranya emosi positif berpengaruh signifikan terhadap belanja impulsif untuk produk yang tergolong mengikuti tren kekinian (Park et al., 2005). Sebaliknya penelitian lainnya menyimpulkan bahwa ketika konsumen berada pada kondisi emosi negatif yang tinggi, perilaku belanja impulsifnya cenderung berkurang (Verplanken \& Sato, 2011).

Sedangkan stimulus lingkungan diantaranya adalah kelompok acuan (reference group) yang digunakan oleh konsumen sebagai kerangka indentifikasi personal untuk memberikan identitas atau mengelompokan orang. Pengaruh kelompok acuan terhadap seorang konsumen dapat meningkat sesuai dengan tingkat kesesuaiannya. Kesesuaian dalam kelompok aspirasional dan non-aspirasional dapat dikontraskan dengan kelompok kohesif dan nonkohesif (Salmon, 2008). Dampak kelompok acuan terhadap belanja impulsif tergantung kepada sifat kelompok acuan itu sendiri, apakah bersifat memberikan pertimbangan, mendorong untuk membeli, atau netral. Salah satu hasil penelitian menyimpulkan bahwa kelompok acuan yang bersifat memberikan pertimbangan berhubungan dengan berkurangnya aktivitas belanja impulsif pada konsumen yang sedang mengalamai emosi negatif yang parah (Overveld, 2016).

Kemudian faktor lainnya yaitu suasana toko (in-store atmosphere), baik yang bersifat fisik maupun non-fisik. Termasuk yang bersifat fisikal adalah peralatan, kebersihan, dan sebagainya, sedangkan yang tergolong non-fisik seperti suhu ruangan dan musik. (Youn \& Faber, 2000). Stimulus tinggi dan lingkungan toko yang nyaman dapat mendorong konsumen meningkatkan keputusan belanja impulsif (Chen T. , 2008). Persepsi stimulasi berlebihan memberikan dampak positif terhadap belanja impulsif yang dipengaruhi secara interaktif dari dua faktor, yaitu faktor sosial yaitu berupa bantuan dari karyawan dan faktor persepsi keramaian (Mattilaa \& Wirtz, 2007). Begitu pula ketika suasana toko mengharuskan para konsumen untuk berbelanja secara terburu-buru, merupakan salah satu alasan penting mengapa konsumen gagal berbelanja sesuai dengan rencana dan pada akhirnya mendorong perilaku belanja impulsif (Hoyer \& MacInnis, 2010).

\section{Stimulus Iklan}

Periklanan adalah bagian dari bauran promosi yang digunakan untuk menginformasikan, membujuk dan mengingatkan konsumen tentang produk/jasa tertentu (Eze \& Lee, 2012). Secara fisik, iklan menampilkan elemen visual seperti huruf dan grafik untuk tujuan menarik minat konsumen. Iklan dapat dilakukan melalui strategi persuasive advertising, yakni strategi mempengaruhi konsumen melalui kualitas produk agar konsumen tersebut mau membeli produk kita, bukan produk perusahaan lain, strenghening advertising yang ditujukan untuk menyakinkan pembeli sekarang bahwa mereka telah melakukan pilihan yang tepat, dan reminder advertising yang ditujukan agar konsumen terus mengingat barang yang diiklankan (Kotler \& Keller, 2007). Pendapat yang sama juga diajukan oleh Zhou \& Wong (2004), yaitu iklan digunakan untuk menginformasikan produk, menginformasikan diskon penjualan dan promosi dan memotivasi konsumen untuk membelinya.

Daya tarik iklan dapat dibedakan antara yang rasional/informasional dengan yang emosional (Lee \& Carla, 2007). Daya tarik rasional fokus pada kebutuhan praktis dan fungsional konsumen akan produk atau jasa. Banyak motif rasional dapat digunakan sebagai basis daya tarik periklanan, termasuk kenyamanan, kemudahan, dan ekonomi. Sedangkan daya tarik emosional menggunakan pesan emosional dan dirancang di sekitar citra yang diharapkan dapat menyentuh hati dan menciptakan respon berdasarkan perasaan dan sikap. 


\section{Positive Electronic Word of Mouth (eWOM)}

Menurut Kotler dan Keller (2007), cerita dari mulut ke mulut (word of mouth) merupakan proses komunikasi yang berupa pemberian rekomendasi baik secara individu maupun kelompok terhadap suatu produk/jasa yang bertujuan untuk memberikan informasi secara personal. Schiffman et al. (2012) mengemukakan bahwa komunikasi juga menghubungkan konsumen dengan lingkungan sosialnya, yaitu komunikasi pemasaran yang berasal dari perusahaan dan berasal dari konsumen. Word of mouth Marketing Association (WOMMA) Mix (2007) dalam Vandaliza (2007) menyatakan bahwa WOM adalah usaha pemasaran yang memicu konsumen untuk membicarakan, mempromosikan, merekomendasikan dan menjual produk/merek kepada pelanggan lain. Menurut Hughes (2005), WOM dapat bersifat positif bila penyampaian informasi tersebut dilakukan oleh individu yang satu ke individu lain berdasarkan pengalaman yang bersifat positif terhadap suatu produk/jasa/penjual, sedangkan negative WOM adalah prses yang sebaliknya.

Komunikasi WOM merupakan sesuatu kekuatan dalam mempengaruhi keputusan pembelian untuk konsumen yang lain, terutama untuk produk-produk yang memiliki risiko bagi konsumennya. WOM memiliki peran penting bagi perusahaan karena dapat menyebar luas secara cepat dan dipercaya oleh para calon konsumen. Penyebaran WOM tidak hanya dapat dilakukan dengan komunikasi dari mulut ke mulut secara tradisional, tetapi juga dapat melalui media sosial seperti aplikasi youtube, whatsapp, line, serta aplikasi lainnya yang terhubung dengan koneksi internet lainnya, yang semuanya dikenal dengan electronic word of mouth (eWOM). Melalui eWOM konsumen dapat saling berinteraksi dengan komunitas jejaring sosialnya, dan internet yang bertindak sebagai katalisator telah mempermudah proses eWOM.

\section{Motif Belanja Hedonis}

Salah satu faktor yang dapat memengaruhi perilaku konsumen dalam membeli barang/jasa, adalah faktor psikologis, termasuk didalamnya adalah motivasi (Armstrong \& Kotler, 2015). Tetapi ketika konsumen pergi ke toko tidak harus membeli sesuatu, banyak alasan atau kebutuhan yang mengapa seseorang mengunjungi atau pergi ke toko, dan alasan inilah yang sering disebut dengan motivasi belanja (shopping motivation). Motivasi menggambarkan kondisi tertekan karena dorongan kebutuhan (needs) yang membuat individu melakukan serangkaian tindakan yang menurut anggapannya dapat memuaskan kebutuhannya. Tindakan yang dipilihnya tersebut didasarkan atas proses berfikir dan proses belajar sebelumnya (Schiffman et al., 2012). Kebutuhan itu dapat bersifat utilitarian (utilitarian needs) bila yang menjadi pertimbangan konsumen adalah kegunaan fungsionalnya, atau dapat bersifat hedonis (hedonic needs) bila lebih mempertimbangkan kemewahannya, gaya hidup, atau kepercayaan diri (Solomon et.al, 2006).

Walaupun konsumen mengunjungi toko tetapi tidak membeli sesuatu, konsumen tetap memperoleh manfaat lain, baik yang bersifat kebendaan (tangible) atau tidak bersifat kebendaan (intangible). Dengan demikian dari sisi motivasi dapat dibedakan antara berbelanja dengan motif memperoleh barang yang memberikan manfaat fungsional (utilitarian shopping) dan berbelanja dengan motif bersenang-senang (hedonic shopping). Sejalan dengan konsep tersebut, beberapa literatur sering mempertentangkan antara utilitarian product dengan hedonic product. Tekanan utilitarian product lebih kepada kegunaan dan kemudahan penggunaannya, sementara hedonic product lebih kepada faktor bersenang-senang (Dennis, 2005). Pada era modern sekarang, motif konsumsi untuk barang-barang tertentu mulai bergeser dari semula dilandasi pertimbangan tujuan fungsional ke arah untuk bersenang-senang yang didorong oleh naluri hedonis (Carpenter, 2008). 
Barang yang bersifat utilitarian umumnya memberikan manfaat praktis dan fungsional kepada pembelinya, sementara yang bersifat hedonis lebih memberikan kesenangan yang tidak bersifat kebendaan (Oliver, 2010) seperti kesenangan, kenikmatan atau kegembiraan. Dengan perkataan lain, konstruk kesenangan biasanya dilekatkan pada belanja hedonis, sementara kegunaan fungsional dan kemudahaan penggunaannya mengarah kepada belanja utilitarian. Berbelanja hedonis dapat disetarakan dengan aktivitas rekreasi seperti halnya berolah-raga, berkesenian atau berwisata. Artinya lebih didasarkan pada aspek perasaan, pikiran dan persepsi, sementara cara ulitarian lebih didorong oleh motivasi rasional-fungsional. Oleh karenanya pengaruh berbelanja hedonis terhadap loyalitas emosional akan lebih besar dibandingkan dengan berbelanja ulitarian karena lebih banyak menggunakan hati dan perasaan daripada rasionalitas (Roy \& Ng, 2012). Belanja hedonis juga sering disetarakan dengan istilah perilaku konsumtif yaitu mengkonsumsi barang-barang yang sebenarnya kurang diperlukan secara berlebihan untuk mencapai kepuasan yang maksimal. Hedonism merupakan teori etika yang memaknai bahwa memperoleh kesenangan atau menghindari kesulitan sebagai sesuatu kebaikan, dan memperoleh sesuatu kesulitan sebagai keburukan (Hopkinson \& Pujari, 1999).

Perilaku utilitarian maupun hedonis dipengaruhi oleh banyak faktor seperti: tingkat rasionalitas (Carpenter, 2008), suasana hati (Donovan et al., 1994), perasaan (Spangenberg et al., 1997), kebiasaan berbelanja (Arnold \& Reynold, 2003), jender (Jackson \& L. Stoel, 2011). Menurut McGuire's typology (Hawkins \& Mothersbaugh, 2010), motivasi belanja hedonis yaitu: bersenang-senang atau berpetualang menemukan barang-barang yang unik/ baru dan menemukan kenikmatan selama proses berbelanja (adventure motivation), bersenang-senang dengan keluarga/teman (social motivation), menghibur diri (gratification/relaxation motivation, memperoleh informasi baru (idea motivation), membeli sesuatu untuk diberikan kepada orang lain (role motivation), dan memperoleh barang yang dijual secara obral/diskon (value motivation). Sementara Ozen \& Engizex (2014) menegaskan motif belanja hedonis adalah menikmati pencarian produk baru (adventure/explore shopping), berburu barang diskon/murah (value shopping), menemukan produk baru (ide shopping), berbelanja dengan teman/kerabat (social shoping), dan berbelanja untuk menghilangkan stres (relaxation shopping). Pendapat yang hampir sama juga diajukan oleh Arnold \& Reynold (2003) yang membagi motif belanja hedonis menjadi enam kategori yaitu: adventure, social, gratification, idea, role, dan value shopping. Ciri belanja hedonis lainnya yaitu konsumen sering menghabiskan watu berlama-lama dan berusaha untuk memperoleh pengalaman kesenangan yang lebih banyak lagi (Berry et al., 2012).

\section{Pengembangan Hipotesis}

Pengaruh iklan terhadap perilaku konsumen diantaranya dikembangkan oleh Mehrabian \& Russel (1974) dalam model stimulus-organism-response (Chang et al., 2011; Chang et al., 2014). Model ini menyatakan iklan adalah stimulus yang dapat mempengaruhi kondisi emosi konsumen dan pada gilirannya akan mendorong untuk berperilaku. Baik pada lingkungan online atau offline, visual iklan berperan penting dalam memengaruhi minat beli konsumen (Chang et al., 2011; Chang et al., 2014; Verhagen \& Van Dolen, 2011; Chang et al., 2015).

Namun menurut hasil penelitian $\mathrm{Hu}$, et al. (2020), dampak iklan terhadap preferensi konsumen tergantung kepada tingkatan kognitif konsumen dan jenis produk yang diiklankan, apakah utilitarian product atau hedonic product. Dalam kaitan ini Drolet et al. (2007) menyatakan bahwa pesan iklan yang rasional lebih banyak ditujukan untuk produk-produk yang bersifat ulitarian, sementara emotional ads lebih populer digunakan untuk membangkitkan motif hedonis konsumennya. Hampir sama, Geuens et al. (2011) juga 
menyatakan bahwa emotional ads lebih efektif untuk mengiklankan barang-barang hedonis. Berdasarkan pertimbangan tersebut maka penelitian ini mengajukan hipotesis (H1a): stimulus iklan berpengaruh positif dan langsung terhadap motif hedonis pembelanja online.

Selain iklan, di era belanja online sekarang ini eWOM merupakan informasi penting bagi konsumen untuk menentukan pilihannya. Ketika konsumen tidak dapat mengamati fisik produk yang akan dibelinya secara langsung maka untuk menghindari risiko, mereka akan mencari informasi dari yang pernah menggunakannya dan bahkan merekomendasikannya. Hal ini sesuai dengan pendapat Wangenheim \& Bayón (2004) yang menyatakan terdapat perbedaan persepsi konsumen terhadap tingkat fungsional dan risiko finansial atas setiap barang yang dibelinya, termasuk yang diperoleh secara online. Hal ini didukung oleh beberapa hasil penelitian seperti Babić et al. (2016) misalnya yang mengungkapkan eWOM adalah salah satu sarana penting yang dapat digunakan konsumen untuk mengurangi kemungkinan risiko atas hedonic product yang dibelinya. Berikutnya Chevalier \& Mayzlin (2006) dan Dellarocas et al. (2007) melaporkan hasil yang sama masing-masing pada industri buku dan perfileman. Atas dasar pertimbangan ini, peneliti mengajukan hipotesis (H1b): $e W O M$ yang positif berpengaruh positif dan langsung terhadap motif hedonis pada pembelanja online.

Stimulus iklan tidak saja dapat membangkitkan motif hedonis pembelanja online, tetapi erat kaitannya dengan perilaku pembelanja impulsif. Penelitian Verhagen \& Van Dolen (2011) menyimpulkan bahwa situs yang menawarkan produk yang sesuai dengan minat konsumen dapat membangkitkan emosi positif konsumen. Berikutnya penelitian Chang et al. (2015) membuktikan iklan yang menarik dan persuasif berdampak positif terhadap preferensi konsumen. Selain itu, perilaku belanja impulsif tidak hanya dipengaruhi oleh keluarga atau teman, role model, dan suasana hati (mood), tetapi juga oleh iklan yang bersifat merekomendasikan (Schiffman et al., 2012). Masih berhubungan dengan iklan, konsumen yang sering berbelanja tanpa rencana tergolong pada kriteria tidak rasional dan mudah dipengaruhi oleh iklan (Rise, 1997). Kemudian penelitian Liu et al. (2013) menyimpulkan bahwa foto produk dalam sebuah iklan yang enak dipandang mata akan mendorong keinginan konsumen untuk membelinya dan berhubungan positif dengan dimensi pembelian gratifikasi. Sementara Pappas et al. (2014) melaporkan iklan sangat relevan dengan lingkungan bisnis online dan berhubungan positif dengan emosi positif konsumen dan niat konsumen untuk membeli. Berdasarkan argumentasi tersebut, maka hipotesis penelitian ini mengajukan hipotesis (H2a): stimulus iklan berpengaruh positif dan langsung terhadap perilaku belanja impulsif pembelanja online.

Penelitian lainnya melaporkan bagaimana hubungan antara eWOM dengan belanja impulsif dan faktor lainnya. Misalnya Jin et al. (2013) menyimpulkan bahwa eWOM berpengaruh positif dan signifikan terhadap perilaku belanja impulsif, baik dalam kasus belanja online maupun toko tradisional. Berikutnya Chen (2010) membuktikan dampak eWoM terhadap belanja impulsif, dan mengkonfirmasi keduanya berhubungan positif. Begitu juga penelitian Ho (2013) mengkonfirmasi hasil yang sama dengan penelitian sebelumnya. Dengan menggunakan variabel moderasi Big 5 Personality Traits, Husnain et al. (2008) melaporkan kesimpulan yang sama. Berdasarkan argumentasi tersebut, maka penelitian ini mengajukan hipotesis (H2b): eWOM yang positif berpengaruh langsung terhadap perilaku belanja impulsif pembelanja online.

Pengaruh dimensi motif hedonis terhadap belanja impulsif telah banyak diteliti, misalnya hubungan antara motif hedonis dengan belanja impulsif yang diungkapkan oleh Rook (1987), Beatty \& Ferrel (1998) dan Peck \& Childers (2006) yang dikuatkan oleh hasil penelitian Dhaundiyal \& Coughlan (2009). Hasil penelitian Kim \& Eastin (2011) mengungkapkan motif hedonis merupakan prediktor yang tepat untuk variabel belanja 
impulsif. Berikutnya studi Galtekin (2012) menyimpulkan bahwa dimensi motif hedonis berdampak positif terhadap belanja impulsif. Sementara untuk pembelanja online, penelitian Zeng, et al. (2019) membuktikan hedonic browsing berpengaruh positif dan langsung terhadap belanja impulsif. Berdasarkan argumentasi tersebut, maka penelitian ini mengajukan hipoteis (H2c): motif hedonis berpengaruh positif dan langsung terhadap perilaku belanja impulsif pembelanja online.

Sebagai implikasi dari hipotesis $\mathrm{H} 1 \mathrm{a}, \mathrm{H} 1 \mathrm{~b}$ dan $\mathrm{H} 2 \mathrm{c}$, maka penelitian ini mengajukan hipotesis (H3a) yaitu: stimulus iklan berpengaruh positif dan tidak langsung terhadap perilaku belanja impulsif melalui variabel mediasi motif hedonis, dan hipotesis $(\mathbf{H 3 b})$ yaitu: eWOM yang positif berpengaruh positif dan tidak langsung terhadap perilaku belanja impulsif melalui variabel mediasi motif hedonis. Secara konseptual, hubungan antar variabel penelitian disajikan pada gambar berikut.

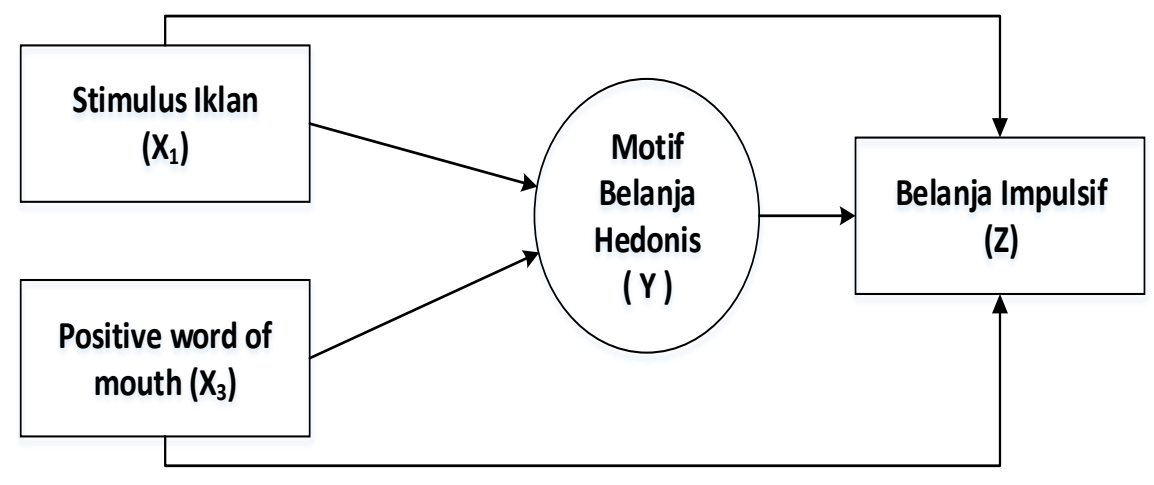

Gambar 1: Model konseptual penelitian

\section{Metode Penelitian}

\section{Desain Penelitian}

Penelitian ini akan melakukan pembuktian empiris terhadap faktor-faktor yang memengaruhi perilaku belanja impulsif konsumen toko online. Karena masalah, tujuan dan karakteristik penelitian ini berhubungan dengan pengukuran masing-masing konstruk, maka dipandang lebih tepat diselesaikan dengan mempergunakan pendekatan kuantitatif yang dilandasi oleh latar belakang filosofis atau worldviews (Creswell, 2014) atau paradigma positivistis (Lincoln \& Guba, 2013). Dilihat dari sisi kemanfaatannya, penelitian ini tergolong pada penelitian terapan (applied research), sedangkan dari sisi tujuannya termasuk pada penelitian deskriptif (Neuman, 2014; Creswell, 2014, Robson \& McCartan, 2016). Sedangkan desain penelitian yang digunakan adalah desain korelasional yaitu menguji dan mengestimasi hubungan banyak variabel baik secara parsial maupun simultan melalui teknik analisis regresi berganda (Creswell, 2012).

\section{Variabel Penelitian}

Dalam penelitian ini, variabel belanja impulsif diwakili oleh empat indikator yaitu: membeli spontan, tanpa banyak pertimbangan, tanpa direncanakan sebelumnya, dan membeli melebihi anggaran. Salah satu faktor yang memengaruhi belanja impulsis, yaitu stimulus iklan, diwakili enam indikator, masing-masing adalah: memberikan informasi produk yang jelas dan lengkap, menyajikan visual yang enak dilihat, dapat berinteraksi dengan konsumen, tidak monoton dan membosankan, memberikan informasi harga, dan memberikan informasi cara pembayaran. 
Faktor kedua adalah positif electronic word of mouth (eWOM) tentang salah satu situs lokapasar dari kelompok acuan (teman atau keluarga) yang dalam penelitian ini diwakili oleh enam indikator, yaitu: frekuensi mendengar keunggulan, frekuensi berdiskusi, frekuensi memperoleh rekomendasi untuk melakukan pencarian (browsing), frekuensi memperoleh rekomendasi untuk membeli barang, frekuensi memperoleh informasi harga, dan frekuensi memperoleh informasi pengiriman barang yang dibeli. Sedangkan variabel motif hedonis diwakili 13 indikator yang terbagi dalam 5 dimensi motif, yaitu gratifikasi /relaksasi, belanja ide/berpetualang, belanja bersosialisasi, belanja nilai dan belanja peran.

\section{Populasi, sampel \& pengumpulan data}

Populasi penelitian ini adalah penduduk Kota Bandung yang pernah berbelanja secara online. Tetapi karena jumlahnya tidak diketahui pasti maka jumlahnya dilakukan melalui perkiraan kasar. Menurut perhitungan Priceza Indonesia yang dikutip oleh Selular.id jumlah pembelanja toko online di Kota Bandung dibandingkan dengan total penduduk adalah 3,09\% tahun 2015, 6,73\% tahun 2016, dan 7,72\% tahun 2017, atau rata-rata naik 2,3\%/tahun (Indra Khairuddin, 2018). Jadi pada tahun 2020 jumlah pembelanja toko online di kota Bandung diperkirakan mencapai 14,6\%. Saat ini penduduk Kota Bandung berjumlah 2,5 juta jiwa, maka jumlah penduduknya yang dapat dianggap sebagai populasi pembelanja toko online diperkirakan mencapai angka 365.000 jiwa.

Dengan menggunakan formula Krejcie \& Morgan, diperoleh ukuran sampel sebanyak 384 orang. Karena tidak tersedia sampling frame, anggota sampel dipilih dengan teknik accident sampling. Data dihimpun dengan menggunakan instrumen kuesioner tertutup, setiap pernyataan diukur dengan skala ordinal, struktur pernyataan kuesioner dirumuskan dalam kalimat positif dan disusun menurut Skala Likerts $(1=$ sangat tidak setuju -5 = sangat setuju $)$.

\section{Analisis Data \& Pengujian Hipotesis}

Sebelum dilakukan pengujian hipotesis, terhadap data penelitian terlebih dahulu dilakukan pengujian validitas dan reliabilitas untuk memastikan bahwa aspek kualiatas data telah terpenuhi. Karena pengujian hipotesis akan dilakukan dengan menggunakan analisis regresi linear berganda (ordinary least square-OLS), maka sebelumnya harus dipastikan bahwa data yang tersedia telah memenuhi persyaratan Best Linier Unbiased Estimator yang meliputi kenormalan residual, linearitas model, masalah otokorelasi dan multikolinearitas.

Karena hubungan antara variabel akan didekati dengan analisis jalur, maka penelitian ini mengkomposisikan hubungan tersebut ke dalam dua jalur dengan persamaan umum sebagai berikut.

Persamaan jalur ke-1: $Y=a+b_{1} X_{1}+b_{2} X_{2}+e \rightarrow Y=\beta_{1} X_{1}+\beta_{2} X_{2}$ Persamaan jalur ke-2: $Z=a+b_{3} X_{1}+b_{4} X_{2}+b_{5} Y+e \rightarrow Z=\beta_{3} X_{1}+\beta_{4} X_{2}+\beta_{5} Y$

$\left(\mathrm{X}_{1}=\right.$ Variabel eksogen stimulus iklan; $\mathrm{X}_{2}=$ Variabel eksogen $e W O M ; \mathrm{Y}=$ variabel endogen motif belanja hedonis; $\mathrm{Z}=$ Variabel endogen belanja impulsif; $\alpha=$ konstanta; $\mathrm{b}_{1}-\mathrm{b}_{5}=$ koefisien regresi; $\beta_{1}-\beta_{5}=$ koefisien jalur; dan e $=$ faktor lain).

\section{Hasil Dan Pembahasan}

\section{Analisis Data Pengujian Hipotesis}

Uji validitas dan reliabilitas

Hasil pengujian validitas mengungkapkan bahwa semua indikator yang digunakan tergolong valid, yaitu untuk variabel stimulus iklan berkisar antara $0.731-0.811$, variabel 
positif $e W O M$ berkisar antara $0.761-0.789$, variabel motif hedonis antara $0.787-0.081$, dan variabel belanja impulsif antara $0.727-0.755$. Sedangkan hasil pengujian reliabilitas menunjukkan semua variabel tergolong dalam kriteria reliabel sehingga mendukung konsistensi internal skala (Gliem \& Gliem, 2003). Nilai Cronbach Alpha untuk variabel stimulus iklan adalah 0.763 , positif $e W O M$ 0.791, motif hedonis 0.801 dan belanja impulsif 0.791 .

\section{Uji asumsi klasik}

Pertama, mengenai kenormalan residual, hasil uji Kolmogorov-Smirnov satu sampel menghasilkan $p$-value $(0.200)>0.05$ sehingga memenuhi kriteria residual harus berdistribusi normal. Kedua, linearitas model diuji dengan menggunakan Uji Glejser dengan kriteria deviation from linearity. Karena $p$-value deviation from linearity semua variabel independen $>0.05$, berarti terdapat hubungan linier antara variabel dependen dengan variabel independen. Ketiga yang berhubungan dengan otokorelasi, diuji dengan kriteria Durbin Watson-test. Hasilnya menunjukkan model penelitian tidak mengandung gejala otokorelasi $(1.732<1.856$ $<$ 2.201). Sedangkan keempat, mengenai gejala multikoliearitas dideteksi dengan menggunakan indikator Tolerance (TOL) dan variance inflation faktor (VIF), hasilnya menunjukkan model regresi terbebas dari masalah multikolinearitas (nilai TOL $>0,10$ atau nilai VIF < 10)

Pengujian hipotesis

Pengujian hipotesis pertama dilakukan pada jalur ke-1, yaitu menguji pengaruh langsung variabel stimulus iklan dan postif eWOM terhadap motif hedonis belanja online. Tabel berikut menjelaskan bahwa variasi motif hedonis dapat dijelaskan oleh variabel stimulus iklan dan positif $e W O M$ sebesar $27 \%$. Artinya masih sangat banyak variabel independen yang mempengaruhi motif hedonis yang tidak dilibatkan dalam model ini. Berikutnya hanya variabel stimulus iklan yang terbukti signifikan positif dan berpengaruh langsung terhadap motif hedonis, yaitu sebesar 39.2\%. Dengan demikian hipotesis penelitian H1a harus diterima secara statistik, dan sebaliknya hipotesis H1b harus ditolak. Tetapi bukan berarti $e W O M$ tidak penting, karena secara bersama-sama dengan variabel stimulus iklan terbukti berpengaruh positif signifikan terhadap motif hedonis pembelanja online $(F=67.91$; p-value $=0.000)$.

Pada jalur kedua, terbukti bahwa stimulus iklan, eWOM dan motif hedonis berpengaruh positif signifikan langsung terhadap perilaku belanja impulsif pembelanja hedonis, masingmasing: 36,9\%, 40.9\% dan 15.4\%. Dengan demikian hipotesis penelitian H2a, H2b dan H2c, harus diterima secara statistik. Karena koefisien variabel stimulus iklan $(p$-value $=0.000)$ dan motif hedonis $(p$-value $=0.027)$ terbukti signifikan, maka hipotesis penelitian H3a yang menyatakan stimulus iklan berpengaruh tidak langsung terhadap perilaku belanja impulsif melalui variabel mediasi motif hedonis, harus diterima secara statistik. Sebaliknya hipotesis penelitian H3b yang menyatakan $e W O M$ berpengaruh tidak langsung terhadap perilaku belanja impulsif melalui variabel mediator motif hedonis harus ditolak secara statistik. 
Tabel 1. Ringkasan hasil analisis jalur

\begin{tabular}{lcrc}
\hline & $\beta$-Coeffcients & $t$-statistics & Significance \\
\hline Jalur-1: & & & \\
Stimulus klan & 0.392 & 2.894 & 0.005 \\
Positif WOM & 0.169 & 1.248 & 0.215 \\
Adjusted $R$-Square & & 0.27 & \\
F-test & & 20.513 & \\
Significance & & 0.000 & \\
Jalur-2: & & & \\
Stimulus klan & 0.369 & 3.894 & 0.000 \\
Positif WOM & 0.409 & 4.46 & 0.000 \\
Motif Hedonis & 0.154 & 2.249 & 0.027 \\
Adjusted $R$-Square & & 0.680 & \\
F-test & & 67.91 & \\
Significance & & 0.000 & \\
\hline
\end{tabular}

Sumber:data diolah

\section{Kesimpulan}

Penelitian ini menguji secara empiris pengaruh stimulus iklan dan eWOM terhadap motif belanja hedonis, serta dampaknya terhadap motif belanja hedonis pembelanja toko online. Hasil penelitian menunjukkan bahwa bahwa stimulus iklan yang dilakukan oleh situs lokapasar berpengaruh positif dan langsung terhadap motif belanja hedonis, tetapi $e W O M$ tidak berpengaruh. Berikutnya terbukti bahwa stimulus iklan, eWOM dan motif belanja hedonis masing-masing berpengaruh positif dan langsung terhadap perilaku belanja impulsif pembelanja online. Temuan lainnya, stimulus iklan berpengaruh tidak langsung terhadap perilaku belanja impulsif melalui variabel mediasi motif hedonis. Namun sebaliknya eWOM tidak berpengaruh tidak langsung terhadap perilaku belanja impulsif melalui variabel mediasi motif hedonis.

Dari sisi praktis, penelitian ini merekomendasikan kepada pengelola situs lokapasar bahwa motif belanja hedonis dan perilaku belanja pembelanja toko online dapat dilakukan terutama melalui strategi pengiklanan yang masif dan persuasif. Penggunaan indikator untuk merepresentasikan masing-masing variabel penelitian masih sangat terbatas dan belum fokus pada kategori produk tertentu yang biasanya dibeli secara online. Akibatnya beberapa temuan yang terungkappun masih terbatas pada lingkup permukaan atau kurang mendalam. Oleh karena itu penelitian ini akan lebih bermakna dan implementatif untuk pengambilan keputusan secara praktis apabila dilanjutkan dengan penelitian-penelitian berikutnya dengan menggunakan rujukan teoritis dan desain penelitian yang lebih memadai, multidimensional, dan melibatkan indikator-indikator yang lebih mewakili. 


\section{Daftar Pustaka}

APJII. (2019). Penetrasi \& Profil Perilaku Pengguna Internet Indonesia. Laporan Survei 2018. Asosiasi Penyelenggara Jasa Internet Indonesia.

Armstrong, G., \& Kotler, P. (2015). Marketing: An introduction (12 ed.). Edinburgh Gate: Pearson.

Arnold, M. J., \& Reynold, K. E. (2003). Hedonic shopping motivations. Journal of Retailing, 79(2), 77-95.

Babić, A., Sotgiu, F., Valck, K. d., \& Bijmolt, T. H. (2016). The Effect of Electronic Word of Mouth on Sales: A Meta-Analytic Review of Platform, Product, and Metric Factors. Journal of Marketing Research, 53(3), 297-318.

Bell, H. A. (2011). A contemporary framework for emotions in consumer decision-making: Moving beyond traditional models. International Journal of Business \& Social Sciences, 2(17), 12-16.

Carpenter, J. M. (2008). Consumer shopping value, satisfaction, loyalty in discount retailing. Journal of Retailing and Consumers Services, 15(5), 358-363.

Chang, H. J., Yan, R.-N., \& Eckman, M. (2014, April 17). Moderating effects of situational characteristics on impulse buying. International Journal of Retail \& Distribution Management, 42(4), 298-314.

Chang, H.-J., Eckman, M., \& Yan, R.-N. (2011). Application of the stimulusorganism-response model to the retail environment: the role of hedonic motivation in impulse buying behavior. International Review of Retail, Distribution \& Consumer Research, 21(3), 233-249.

Chang, Y.-T., Yu, H., \& Lu, H.-P. (2015). Persuasive messages, popularity cohesion and message diffusion in social media marketing. Journal of Business Research, 68, 777 782.

Chen, T. (2008, February). Impulse purchase varied by products and marketing channel. Journal of International Management Studies, 154-161.

Chen, Y.-W. (2010). Using emotion as mediator to explore the effects of information characteristics of eWOM on impulse buying behavior. Master Thesis, the Graduate Institute of Commerce Automation and Management. Taiwan: National Taipei University of Technology.

Chevalier, J. A., \& Mayzlin, D. (2006). The Effect of Word of Mouth on Sales: Online Book Reviews. Journal of Marketing Research, 43(3), 345-354.

Creswell, J. W. (2014). Research Design: Qualitative, Quantitative, \& Mixed Methods Approaches (4th ed.). London: Sage Publications, Ltd.

Dellarocas, C., Zhang, X., \& Awad, N. F. (2007). The Effect of Electronic Word of Mouth on Sales: A Meta-Analytic Review of Platform, Product, and Metric Factors. Journal of Interactive Marketing, 21(4), 23-45.

Dennis, C. (2005). Objects of desire: Consumer behaviour in shopping centre choise. New York: Palgrave Macmillan.

Dhaundiyal, M., \& Coughlan, J. (2009). The Effect of Hedonic Motivations, Socialibility and Shyness on the Implusive Buying Tendencies of the Irish Consumer. Conference Paper, 1-31. Dublin: Irish Academy of Management.

Donovan, R. J., Rositter, J., Marcoolyn, G., \& A. Nesdale. (1994). Store atmosphere and purchasing behavior. Journal of marketing, 70(3), 283-294.

Drolet, A., Williams, P., \& Lau-Gesk, L. (2007). Age-related differences in responses to affective vs. rational ads for hedonic vs. utilitarian products. Marketing Letters, 18(4), 211-221. 
E.Beatty, S., \& Ferrell, M. E. (1998, Summer). Impulse buying: Modeling its precursors. Journal of Retailing, 74(2), 169-191.

Eze, U. C., \& Lee, C. H. (2012). Consumers' attitude towards advertising. Journal of Business and Managemen, 7(13), 94-108.

Galtekin, B. (2012). The Influence of Hedonic Motives and Browsing On Impulse Buying. Journal of Economics and Behavioral Studies, 4(3), 180-189.

Geuens, M., Pelsmacker, P. D., \& Faseur, T. (2011). Emotional advertising: revisiting the role of product category. Journal of Business Research, 64(4), 418-426.

Gliem, J. A., \& Gliem, R. R. (2003). Calculating, Interpreting, And Reporting Cronbach's Alpha Reliability Coefficient For Likert-Type Scales. Midwest Research-to-Practice Conference in Adult, Continuing, and Community Education (pp. 82-88). Ohio: The Ohio State University.

Hawkins, D. I., \& Mothersbaugh, D. L. (2010). Consumer behavior: building marketing strategy. New York: McGraw-Hill/Irwin.

Hopkinson, G., \& Pujari, D. (1999). A factor analytic study of the sources of meaning in hedonic consumption. European Journal of Marketing, 33(3/4), 273-294.

Hoyer, W. D., \& MacInnis, D. J. (2010). Consumer behavior (5th ed.). Mason: South-Western, Cengage Kearning.

Hu, F., Wu, Q., Li, Y., Xu, W., Zhao, L., \& Sun, Q. (2020). Love at First Glance but Not After Deep Consideration: The Impact of Sexually Appealing Advertising on Product Preferences. Frontier in Neuroscience, 14(465).

Hughes, M. (2007). Buzzmarketing: Get People to Talk about Your Stuff. New York: Penguin Putnam Inc.

Husnain, M., Qureshi, I., Fatima, T., \& Akhtar, W. (2016). The Impact of Electronic Word-ofMouth on Online Impulse BuyingBehavior: The Moderating role of Big 5 Personality Traits. Journal of Accounting \& Marketing, 5(4), 1-9.

Indra Khairuddin. (2018, Juni 26). 5 Kota ini Paling Banyak Jumlah Pembelanja Online. Berita. Selular.id. Retrieved 16/08/2020, from https://selular.id/2018/06/5-kota-ini-palingbanyak-jumlah-pembelanja-online/

J.Arnold, M., \& E.Reynolds, K. (2003). Hedonic shopping motivations. Journal of Retailing, 79(2), 77-95.

J.Kacen, J., \& Lee, J. A. (2002). The influence of culture on consumer impulsive buying behavior. Journal of Consumer Psychology, 12(2), 163-176.

Jackson, V., \& L. Stoel. (2011). Mall attributes and shopping value: Difference by gender and generational cohort. Journal of Retailing and Consumer Services, 18(1), 1-9.

Kim, S., \& Eastin, M. S. (2011). Hedonic Tendencies and the Online Consumer: An Investigation of the Online Shopping Process. Journal of Internet Commerce, 10(1), 68-90.

Kotler, P., \& Keller. (2007). Manajemen Pemasaran (12 ed., Vol. 1). Jakarta: PT. Indeks.

Lee, M., \& Carla, J. (2007). Prinsip-prinsip Pokok Periklanan dalam Perspektif Global (2nd ed.). Jakarta: Kencana.

Liu, Y., Li, H., \& Hu, F. (2003, April 11). Website attributes in urging online impulse purchase: An empirical investigation on consumer perceptions. Decision Support Systems, 55(3), 829-837.

Li-yin, J., Cheng, T., \& Shih, H.-p. (2013). The study of positive and negative electronic wordof mouth on goal-directed and impulsive buying behavior. Electronic Commerce Studies, 11(1), 1-28. 
Mattilaa, A. S., \& Wirtz, J. (2007). The role of store environmental stimulation and social factors on impulse purchasing. Journal of Service Marketing, 2(7), 273-289.

Neuman, W. L. (2007). Basic of Social Research: Qualitative \& Quantitative Approaches (2nd ed.). Pearson Education, Inc.

Oliver, R. L. (2010). Satisfaction: A behavioral perspective on the consumer (2nd ed.). London: Routledge.

Overveld, M. v. (2016). Emotion regulation can be costly. A study on the effects of emotion regulation strategies on impulsive purchases in consumers. Innovative Marketing, 12(1).

Ozen, H., \& Engizek, N. (2014). Shopping online without thinking: being emotional or rational? Asia Pacific Journal of Marketing and Logistics, 26(1), 78-93.

Pappas, I. O., Kourouthanassis, P. E., Giannakos, M. N., \& Chrissikopoulos, V. (2014). Shiny happy people buying: the role of emotions on personalized e-shopping. Electron Markets, 24(3), 193-206.

Park, E. J., Kim, E. Y., \& Forney, J. C. (2006). A structural model of fashion-oriented impulse buying behavior. Journal of Fashion Marketing and Management, 10(4), 433-446.

Peck, J., \& L.Childers, T. (2006, June). If I touch it I have to have it: Individual and environmental influences on impulse purchasing. Journal of Business Research, 59(6), 765-769.

Rise, C. (1997). Understanding customer (2nd ed.). Oxford: Butterworth-Heinemann.

Rook, D. W. (1987, September). The Buying Impulse. Journal of Consumer Research, 14(2), 189-199.

Roy, R., \& Ng, S. (2012). Regulatory focus and preference reversal between hedonic and utilitarian consumption. Journal of Consumer Behaviour, 11(1), 81-88.

Salmon, D. N. (2008). Reference groups: Aspirational and non-aspirational groups in consumer behavior. Xavier University of Louisiana's Undergraduate Research Journal, 5(1), 18.

Schiffman, L. G., Kanuk, L. L., \& Hansen, H. (2012). Consumer behavior: An European outlook (2nd ed.). England: Pearson Education Limited.

Silvera, D. H., Lavack, A. M., \& Kropp, F. (2008). Impulse buying: The role of affect, social influence, and subjective wellbeing. Journal of Consumer Marketing, 25(1), 23-33.

Solomon, M., Bamossy, G., Askegaard, S., \& Hogg, M. K. (2006). Consumer behavior: A European Perspective (3rd ed.). Harlow: Pearson Education Limited.

Spangenberg, E. R., Voss, K. E., \& A E. Crowley. (1997). Measuring the hedonic and utilitarian dimensions of attitude: A generally applicable scale. Advances in Consumer Research, 24(1), 235-241.

Tice, D. M., Bratslavsky, E., \& Baumeister, R. F. (2001). Emotional distress regulation takes precedence over impulse control: If you feel bad, do it. ournal of Personality and Social Psychology, 80(1), 53-67.

To, P.-L., Liao, C., \& Tzu-HuaLin. (2007, December). Shopping motivations on Internet: A study based on utilitarian and hedonic value. Technovation, 27(12), 774-787.

Verhagen, T., \& Dolen, W. v. (2011, December). The influence of online store beliefs on consumer online impulse buying: A model and empirical application. Information \& Management, 48(8), 320-327.

Verplanken, B., \& Sato, A. (2011). The psychology of impulse buying: An integrative selfregulation approach. Journal of Consumer Policy, 34(2), 197-210 . 
Wangenheim, F. v., \& Bayón, T. (2004). The effect of word of mouth on services switching: Measurement and moderating variables. European Journal of Marketing, 38(9/10), 1173-1185.

Youn, S., \& Faber, R. J. (2000). Impulse buying: Its relation to personality traits and cues. Advances in Consumer Research, 27, 179-185.

Zheng, X., Men, J., Yang, F., \& Gong, X. (2019, October). Understanding impulse buying in mobile commerce: An investigation into hedonic and utilitarian browsing. International Journal of Information Management, 48, 151-160.

Zhou, L., \& Wong, A. (2004). Consumer Impulse Buying and In-Store Stimuli in Chinese Supermarkets. Journal of International Consumer Marketing, 16(2), 37-53. 